\title{
Renewable energy as an integral part of the Bulgarian energy mix
}

\author{
Todorka Stankova ${ }^{1, *}$, and Daniela Toneva ${ }^{2}$ \\ ${ }^{1,2}$ Technical University of Varna, Department Ecology and Environmental Protection, 9010 Varna, \\ Studentska str., Bulgaria
}

\begin{abstract}
An economy with net-zero greenhouse gas emissions is the new EU 2050 is a main long- term strategic objective, which follows the EU RES promotion policy. Investment in renewable energy is a key factor for reduction of the conventional energy sources' carbon footprint. The transition from conventional to green energy is an on-going process. The renewable energy becomes an integral part from the energy mix of EU countries, including Bulgaria. Current research on RES component of Bulgarian energy mix covers the period from 2007 to 2019. It reveals the internal renewable energy subsector structure. The preconditions for solar and wind energy project are analysed, together with the levels of RES energy production in Bulgaria. The Bulgaria RES sector incoherence is highlighted. Some trends of RES development in the context of gross final energy production and consumption are revealed. Some gaps in Bulgarian practices regarding RES promotion policy implementation are identified and discussed.
\end{abstract}

\section{Introduction}

By 2050, Europe aims to become the world's first climate-neutral continent [1]. Renewable energy share in the total EU energy mix was doubled between 2004 and 2019 but at the same time the European environmental agency reported that around $90 \%$ of city dwellers in Europe are exposed to pollutants at concentrations higher than the air quality levels deemed harmful to health [2].These facts unambiguously confirm that the anthropological impact on the environment develops faster than it can be counteracted. According to Eurostat over the past decade (2008-2018), the trend in primary energy production was generally negative for solid fossil fuels, oil, natural gas and nuclear energy. The production of natural gas and oil and petroleum products accounted for the biggest decreases (with $46.4 \%$ and $35.3 \%$ respectively) while solid fossil fuels production fell by $27.9 \%$ [3]. However, there was a positive trend in the production of renewable energies (RE) over the same period (with an exception in 2011), with a $49.2 \%$ increase, as well as for waste (nonrenewable) with a $46.0 \%$ increase $[3,8]$. At the same time the data shows that the exports are much lower than imports which make the EU still energy dependence.

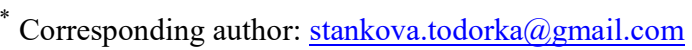




\section{Discussions}

Due to the progress in renewable energy field Bulgaria declared that the 20/20/20 targets had been achieved and $18,6 \%$ is the share of the gross final energy consumption produced by renewable sources [4].The gross final energy consumption from renewable energy sources in 2017 and 2018 was 2,037.8ktoe and 2,226.1ktoe, and compared to the previous reporting period (2015-2016) it increased by an average of $9.2 \%$. Important for the achieved increase is the larger amount of solid biomass used in 2018 for the production of heat and/or electricity in thermal power plants, as well as the increase in the use of hydropower. In 2018, the solid biomass used for energy production (398.5ktoe) is almost 9 times more than in 2017 (47.8ktoe) [4].

In the period 2017-2018 there is an increase in the installed capacity for the production of electricity from biomass, which in 2018 reached 195MW. Compared to 2017, the installed capacity of this type of power plants has increased almost 4 times. A change is also reported in hydropower plants (HPPs), where the change in 2018 compared to 2017 is mainly due to the commissioning of rehabilitated facilities. The new HPPs introduced in 2017 and 2018 are 5.2MW, respectively. In wind and photovoltaic power plants, the installed capacity is almost unchanged [4].

The production of electricity from renewable energy sources in the period 2017-2018 increased by $10.5 \%$, which is due to the significant increase in electricity produced from solid biomass and in lower growth rate in electricity production from HPPs and HPPs [4].

Table 1. Calculation table for the renewable energy contribution of each sector to final energy consumption, ktoe

\begin{tabular}{|l|l|l|l|l|l|l|l|l|}
\hline & $\mathbf{2 0 1 1}$ & $\mathbf{2 0 1 2}$ & $\mathbf{2 0 1 3}$ & $\mathbf{2 0 1 4}$ & $\mathbf{2 0 1 5}$ & $\mathbf{2 0 1 6}$ & $\mathbf{2 0 1 7}$ & $\mathbf{2 0 1 8}$ \\
\hline $\begin{array}{l}\text { Gross final } \\
\text { consumption of RES } \\
\text { for heating and } \\
\text { cooling }\end{array}$ & 1043.3 & 1122.0 & 1142.5 & 1087.3 & 1146.6 & 1203.0 & 1229.2 & 1345.2 \\
\hline $\begin{array}{l}\text { Gross final } \\
\text { consumption of } \\
\text { electricity from RES }\end{array}$ & 420.7 & 514.7 & 586.7 & 595.8 & 614.9 & 620.8 & 636.2 & 729.8 \\
\hline $\begin{array}{l}\text { Gross final } \\
\text { consumption of } \\
\text { energy from RES in }\end{array}$ & 6.0 & 5.1 & 105.7 & 114.9 & 149.9 & 168.6 & 172.4 & 151.1 \\
\hline $\begin{array}{l}\text { Gross total } \\
\text { RES } \\
\text { consumption }\end{array}$ & 1470.0 & 1641.8 & 1834.9 & 1798.0 & 1911.5 & 1992.4 & 2037.8 & 2226.1 \\
\hline
\end{tabular}

A National energy plan and climate plan of Republic of Bulgaria for the period 2021-2030 was already accepted by the Ministry of Energy and the Ministry of Environment and Water. In order to achieve the set new national target of $27.09 \%$ share of renewable energy in the gross final energy consumption by 2030, existing as well as additional policies and measures will be applied [5]. As an appropriate form of support, the possibility of conducting tenders for the provision of capacity for the production of electricity from renewable energy sources and the provision of a supplement in the form of a premium to the market price for the electricity sold on the electricity market is also considered.

In the period 2020-2030, an increase of 2,645 MW in the net installed capacity of power plants using renewable energy is expected. This growth was accompanied by an increase in 
the net installed capacity of photovoltaic power plants (PV) by 2,174 MW and of wind power plants only by 249MW[5]. The photovoltaic energy production was the most promoted in the country during the past years and is planned to be the most developed source till 2030 . Noting that the electricity productivity per unit area compared by wind and solar energy is in favour of the wind energy, the planned till 2030 by the Bulgarian government 8,73 times more photovoltaic than wind energy is incomprehensible. Creating a map which provides information about the potential, the grid balance need and capacity can support the renewable energy sources development in complex, avoiding predominance of some sources over another and insuring grid balance in the production.

Table 2. Forecast - RES development in Bulgaria, 2020-2030, MW

\begin{tabular}{|l|r|r|r|r|r|r|r|r|r|r|r|}
\hline \multicolumn{6}{|c|}{ Forecast for the net installed capacity of renewable power plants for the period 2020-2030, MW } \\
\hline \hline & $\mathbf{2 0 2 0}$ & $\mathbf{2 0 2 1}$ & $\mathbf{2 0 2 2}$ & $\mathbf{2 0 2 3}$ & $\mathbf{2 0 2 4}$ & $\mathbf{2 0 2 5}$ & $\mathbf{2 0 2 6}$ & $\mathbf{2 0 2 7}$ & $\mathbf{2 0 2 8}$ & $\mathbf{2 0 2 9}$ & $\mathbf{2 0 3 0}$ \\
\hline $\begin{array}{l}\text { Hydro power } \\
\text { plants }\end{array}$ & 2508 & 2508 & 2508 & 2508 & 2508 & 2508 & 2508 & 2508 & 2508 & 2508 & 2508 \\
\hline Wind energy & 699 & 709 & 719 & 729 & 739 & 749 & 788 & 828 & 868 & 908 & 948 \\
\hline PV & 1042 & 1191 & 1339 & 1488 & 1636 & 1785 & 2071 & 2357 & 2643 & 2930 & 3126 \\
\hline Biomass & 80 & 114 & 149 & 184 & 219 & 253 & 263 & 273 & 282 & 292 & 302 \\
\hline Total & $\mathbf{6 3 4 9}$ & $\mathbf{6 5 4 3}$ & $\mathbf{6 7 3 7}$ & $\mathbf{6 9 3 2}$ & $\mathbf{7 1 2 6}$ & $\mathbf{7 3 2 0}$ & $\mathbf{7 6 5 6}$ & $\mathbf{7 9 9 3}$ & $\mathbf{8 3 2 9}$ & $\mathbf{8 6 6 7}$ & $\mathbf{8 9 1 4}$ \\
\hline
\end{tabular}

Another gab which is visible from the Bulgarian national action and climate plan is the obligatory of the EU due to coal and lignite Thermal Power Plants (TPP) cessation activity. Nowadays Bulgaria relay on $4555 \mathrm{MW}$ TPP installed capacity. The determination of the $\mathrm{CO}_{2}$ emissions in the European Union is a role of both renewable and not renewable energy [6]. Till 2025 the Bulgarian government has to adopt an action plan of cancelling that conventional and pollutant energy production.

Table 3. Installed capacity in \% by type of course, Bulgaria 2019

\begin{tabular}{|l|r|r|}
\hline Type of power plant & \multicolumn{2}{|c|}{$\begin{array}{c}\text { Installed capacity in \%, } \\
\text { Bulgaria 2019 }\end{array}$} \\
\hline Nuclear power plant & 2000 & Share in \% \\
\hline Thermal power plant-lignite & 4199 & 15,7 \\
\hline Termal power plant-coal & 356 & 32,2 \\
\hline Termal power plant-gas & 1235 & 2,8 \\
\hline Hydropower plant & 3211 & 9,7 \\
\hline Wind power plant & 701 & 25,2 \\
\hline Photovoltaic power plant & 1059 & 5,5 \\
\hline Biomass power plant & 77 & 8,3 \\
\hline
\end{tabular}


Data of the Energy system operator (ESO) about the share in the energy mix in Bulgaria is provided in the following table. About $50 \%$ of the electricity production is done by state own companies as the nuclear power station Kozloduy and some of the Thermal power plans (coal) and Hydro power plant (and pump hydro power plant). All renewable energy projects are private as well as some of the Thermal power plant.

According to the Bulgarian national action and climate plan by 2030 only $2645 \mathrm{MW}$ renewable energy sources are expected to be erected when 4555MW (from the thermal lignite and coal TPP) has to be cut off the grid. This make concerns about the energy security of the state at all. An adequate and immediate energy policy changes have to be adopted and implemented in order to insure the Bulgarian population and business with enough energy sources.

In 2017 and 2018, the Republic of Bulgaria achieved a share of energy from renewable sources equal to $18.7 \%$ and $20.49 \%$ of the gross final energy consumption in the country, respectively. The established values show exceeding the intermediate targets of the National Action Plan for Renewable Energy for the indicated years by 5 and 6.79 percentage points, and overfulfillment of the national mandatory target for 2020 of $16 \%$ share of renewable energy in gross final energy consumption.

The progress made is due to higher energy consumption from renewable sources in the heat and cooling and electricity sectors [4]. The state continually report the all wood used for household purposes as a biomass which doesn't respond to the sustainable criteria of paragraph 1 of Article 5 of the Directive, detailed reviewed in a previous science work of our team which accurse another concern about the real achieved share in the RES gross final energy consumption of the state [7].

In line with the EC's Third Liberalization Package [10], Bulgaria has taken steps towards full liberalization of the electricity market. As a result of legal changes from the beginning of 2018, the entire amount of electricity produced for the free market is traded only on the trading platforms of the IBEX. The liberalization of the electricity market is in force since 2007. The process was done step by step. Till October 2020 all industrial/non household consumers had to choose their own supplier with own price and till 2021 also all households will have the right to do it. Customers are not more obliged to choose the grid operator of their region of living as it was before. The Power Exchange Operational Rules (PEOR) regulate the organization of the activities, rights and obligations of the power exchange operator and all trading participants on the organized power exchange market for electricity. The Power exchange operator administrates three market segments- Intraday, Day-ahead and Bilateral contracts.

Pursuant to changes to the Energy Act published in State Gazette, 79/2019, the Energy and Water Regulatory Commission (EWRC) shall approve operational rules for organized power exchange market for electricity (art. 21, par. 1, item 42 EA). In this regard, on 19th June 2020, in issue 55 of State Gazette Power Exchange Operational Rules were approved for the first time by EWRC [5].

Wholesale baseload electricity prices 4-th quarter of 2019, Euro per MWh, Bulgaria 46,6Euro/MWh. Compared to Netherland, Germany, Belgium, France. The price in Bulgaria is on the top margin. For the whole 2019 the average price for day-ahead by IBEX on the base $/ 1-24 \mathrm{~h} /$ was $47,37 € / \mathrm{MWh}[3,9,11]$. 


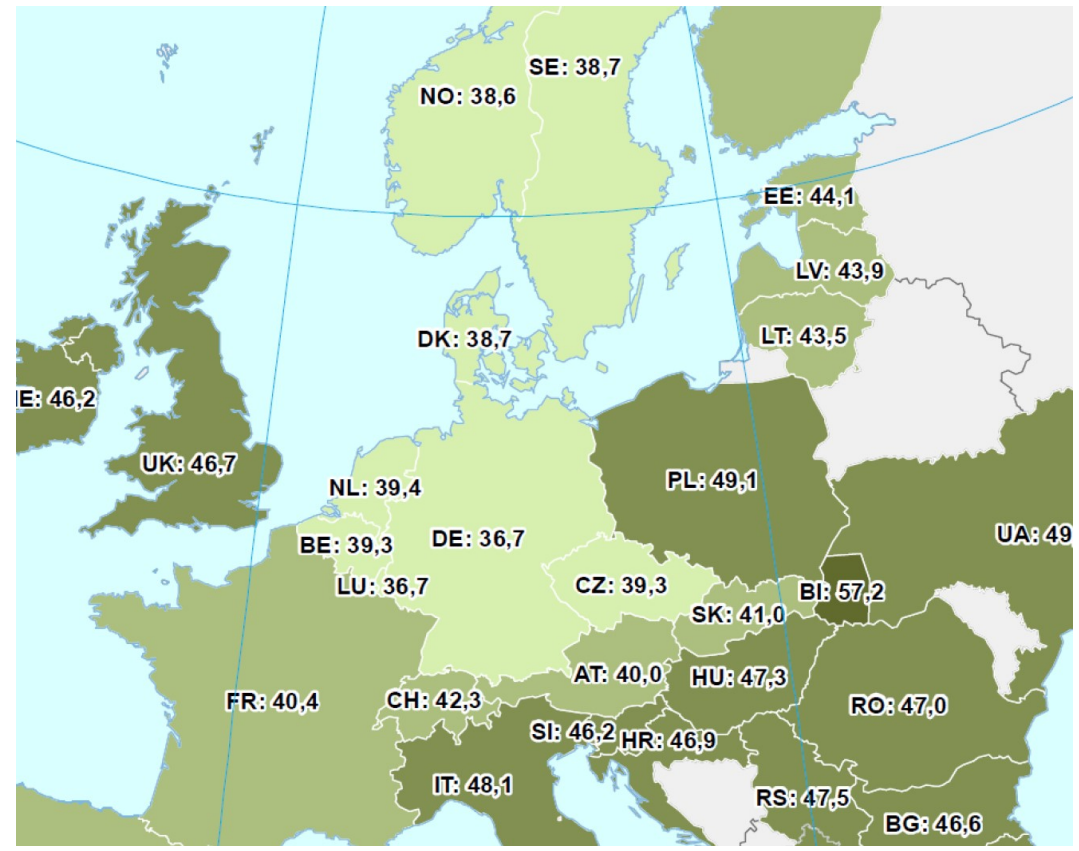

Fig. 1. Wholesale baseload electricity prices 4-th quarter of 2019, Euro per MWh.

Despite the fact that new renewable energy courses were installed during the past years, Bulgaria still have very high percentage of electricity energy dependency which is clearly visible from table 4. Having all the above mentioned fact the state still didn't run into operation the statistical transfer methods means that the Bulgarian end consumer is obliged to consume all RES energy and all bordering country can import only energy from the TPP or the Nuclear power plant [6,7]. This allows the government artificially to control the energy mix and the energy consumption.

Table 4. Energy dependence, Bulgaria 2019, \%

\begin{tabular}{|l|r|r|r|r|r|}
\hline \multicolumn{5}{|c|}{ Energy dependency } & \% \\
\hline & $\mathbf{2 0 1 4}$ & $\mathbf{2 0 1 5}$ & $\mathbf{2 0 1 6}$ & $\mathbf{2 0 1 7}$ & $\mathbf{2 0 1 8}$ \\
\hline Energy dependency & 35,3 & 36,5 & 38,6 & 39,5 & 36,5 \\
\hline
\end{tabular}

\section{Conclusions}

The photovoltaic energy production is the most promoted in the country. More than $70 \%$ of the planned renewable energy installations have to use the solar irradiation as a source till 2030 [5]. There is a categorical imbalance in the forecast, noting the area interaction of solar compared to wind. If on 500sq.m plot of land a $3 \mathrm{MW}$ wind turbine could be installed, than for the same installed capacity of standing PV power plant approximately 60000 sq.m will be needed together with service areas included.

From the Forecast in RES development in Bulgaria it is absolutely clear that even till 2030 , the planned increase of $2645 \mathrm{MW}$ by renewable sources isn't enough for the energy security of Bulgaria $[5,6,7]$. The option of change of the raw material coal or lignite with gas has a very low efficiency- up to $25 \%$ and isn't an appropriate solution for investors, so $4555 \mathrm{MW}$ TPP installed capacity have to cut off the grid within less than 5 years. This is 
$35 \%$ of the whole energy mix in the country and the lack of an action plan of cancelling and replacing that conventional and pollutant energy production of the state make the energy security risk higher.

The possibility of the government for artificial control of the share in RES energy consumption by the Bulgarian citizens and entities by counting all household used woods in the part of biomass as well as the lack of statistical methods for transferring renewable energy to other counties confirms that major change in the energy policy is imperative.

The lack of balance between the renewable energy sources erection and the promotion of one above another is discriminatory and once more confirmed by the written in the 5-th RES progress report and the National action and climate plan, data.

All that mentioned above facts make concerns about the Bulgarian energy development market up to 2030 and the energy security especially after 2025 when the TPP have to cease their activity. Nevertheless the European Union have an action plan by 2050 which is missing in Bulgaria.

Part of the results of the present research were obtained under the National program "Young scientists and postdoctoral students", financed by the Ministry of Education and Science of Bulgaria.

\section{References}

1. The European Green Deal, communication from the commission COM (2019) 640 final, Brussel (2009) https://eur-lex.europa.eu/legalcontent/EN/TXT/?qid=1596443911913\&uri=CELEX:52019DC0640\#document2

2. S. Angheluta, S. Burlacu, A. Diaconu, C.Curea, European Journal of Sustainable Development, Vol.8, №5; Special issue, p.57-65, (2021)

3. Eurostat, Renewable energy in the EU in 2018, news release 17/2020-(2020) https://ec.europa.eu/eurostat/documents/2995521/10335438/8-23012020-APEN.pdf/292cf2e5-8870-4525-7ad7-188864ba0c29

4. Fifth Renewable energy progress report, European Commission, at all (2020)

5. National energy and climate plan of Bulgaria 2021-2030, p.68-70 (2020)

6. E. Dogan, F. Seker, Determinants of $\mathrm{CO}_{2}$ emissions in the European Union: The role of renewable and non-renewable energy, Renewable energy, Vol. 94, p.429-439 (2016)

7. T. Stankova, D.Toneva 2021 IOP Conf. Ser.: Material Science and Engineering 1032 012027 (2020)

8. J. Brodny, M.Tutak, Analyzing Similarities between the European Union Countries in Terms of the Structure and Volume of Energy Production from Renewable Energy Sources, Energies, Vol. 13, Issue 4/10.3390, p.3-37 (2020)

9. M.Pacesila, S. Burcea, S. Colesca, Analysis of renewable energies in European Union, Renewable and Sustainable Energy Reviews, Vol.56, p.156-170, (2016)

10. P. Eikeland, The Third Internal Energy Market Package: New Power Relations among Member States, EU Institutions and Non-state Actors. Journal of common market studies, Vol.49, Issue 2, p. 243-263 (2011)

11. S. Djorup, J. Thellufsen, P. Sorknas, The electricity market in a renewable energy system, Energy, Vol. 162, p. 148-157 (2018) 